\title{
ANALISA KADAR AIR, pH, DAN KAPANG PADA IKAN CAKALANG (Katsuwonus pelamis, L) ASAP YANG DIKEMAS VAKUM PADA PENYIMPANAN SUHU DINGIN
}

\author{
David Hadrianus Kaban ${ }^{1}$, Semuel M. Timbowo ${ }^{2}$, Engel V. Pandey², Hanny W. Mewengkang², \\ Joyce C.V Palenewen ${ }^{2}$, Feny Mentang', Verly Dotulong ${ }^{2}$
}

${ }^{1}$ Mahasiswa pada Program Studi Teknologi Hasil Perikanan FPIK UNSRAT Manado.

${ }^{2}$ Staf Pengajar pada Program Studi Teknologi Hasil Perikanan FPIK UNSRAT Manado.

E-mail: davidhadrianuskaban@gmail.com

\begin{abstract}
Fish is one of the ingredients that easily experiences quality deterioration. Fish quality deterioration is caused by enzymatic action and bacterial action. Both of these actions describe the constituent components of the fish's body tissue so as to produce physical changes such as soft meat and chemical changes that produce volatile and foul-smelling compounds. The purpose of this study was to analyze and compare the amount of moisture, $\mathrm{pH}$, and mold in Cakalang Asap Fish (Katsuwonus pelamis, L) Vacuum packaged by the Vacuum at Cold Temperature Storage for 0 to 7 days. The method of analysis used is descriptive data carried out by collecting and presenting information according to the results of testing in the Laboratory. The research method used is an explorative experimental method of expressing facts based on existing problems through hypotheses. Explorative experimental research is exploration which aims to find problems or the development of hypotheses about causal or symptomatic relationships. The treatments carried out in this study were $0-7$ days with repetitions carried out, namely 2 times. From the research results obtained; the highest water content value in smoked skipjack originating from the Sario Fish Market (62.5\%) storage 0-7 days, the lowest (55\%) storage for 0 days on smoked skipjack tuna processed by themselves; the highest $\mathrm{pH}$ value of 6.25 in smoked skipjack from Sario Market 7 days storage and the lowest 5.640 days storage in self-processed smoked skipjack; The total value of the highest fungus colonies of $8.9 \times 10^{3}$ on smoked skipjack from fish sellers in Sario is the $7^{\text {th }}$ and lowest day storage of $1.3 \times 10^{3}$ in smoked skipjack from fish sellers in Sario for the $0^{\text {th }}$ day storage but mold values from both samples do not meet SNI (2013).
\end{abstract}

Keyword: Analysis of Water, pH and Cakalang Fish Mushroom, Katsuwonus pelamis, L., Vacuum Packed Vacuum in Cold Storage.

Ikan merupakan salah satu bahan makanan yang mudah mengalami kemunduran mutu. Kemunduran mutu ikan disebabkan oleh aksi enzimatis dan aksi bakteri. Kedua aksi ini menguraikan komponen penyusun jaringan tubuh ikan sehingga menghasilkan perubahan fisik seperti daging ikan menjadi lunak dan perubahan kimia yang menghasilkan senyawa mudah menguap dan berbau busuk. Tujuan dari penelitian ini adalah untuk menganalisa dan membandingkan jumlah kadar air , $\mathrm{pH}$ dan kapang pada ikan cakalang asap (Katsuwonus pelamis, L) asap yang dikemas vakum pada penyimpanan suhu dingin selama 0-7 hari. Metode Analisa yang digunakan yaitu data deskriptif dilakukan dengan pengumpulan dan penyajian informasi sesuai dari hasil pengujian di Laboratorium. Metode penelitian yang digunakan adalah metode eksperimen eksploratif yaitu mengungkapkan fakta-fakta berdasarkan problema yang ada melalui hipotesa. Penelitian eksperimen eksploratif adalah penjelajahan yang bermaksud mencari problema-problema atau pengembangan hipotesa tentang hubungan sebab akibat atau gejala. Perlakuan yang dilakukan dalam penelitian ini yaitu 0-7 hari dengan pengulangan yang dilakukan yaitu sebanyak 2 kali. Dari hasil penelitian diperoleh; nilai kadar air tertinggi pada ikan cakalang asap yang berasal dari Pasar ikan Sario $(62,5 \%)$ penyimpanan $0-7$ hari, terendah $(55 \%)$ penyimpanan 0 hari pada ikan cakalang asap yang diolah sendiri; nilai $\mathrm{pH}$ tertinggi 6,25 pada ikan cakalang asap dari Pasar Sario penyimpanan 7 hari dan terendah 5,64 penyimpanan 0 hari pada ikan cakalang asap yang diolah sendiri. Nilai total koloni kapang tertinggi $8,9 \times 10^{3}$ pada ikan cakalang asap dari penjual ikan di Sario penyimpanan hari ke 7 dan terendah $1,3 \times 10^{3}$ pada ikan cakalang asap dari penjual ikan di Sario penyimpanan hari ke 0 namun nilai kapang dari kedua sampel sudah tidak memenuhi SNI (2013).

Kata kunci: Analisa Kadar Air, pH dan Kapang Ikan Cakalang, Katsuwonus pelamis, L., asap yang Dikemas Vakum pada penyimpanan dingin.

\section{PENDAHULUAN}

Ikan merupakan salah satu bahan makanan yang tidak asing lagi bagi masyarakat
Indonesia, bahan makanan ini memiliki kelebihan yaitu mengandung asam amino essensial yang diperlukan oleh tubuh, disamping itu nilai biologisnya mencapai $90 \%$ 
dengan jaringan pengikat sedikit sehingga mudah dicerna (Adawyah, 2007).

Ikan cakalang asap yang diproduksi di Sulawesi Utara ditemukan dipasaran terdapat dua bentuk, yaitu utuh dan yang dijepit dengan bambu. Jika ukuran ikan cakalang berukuran berat $>1,5 \mathrm{Kg}$ ikan diolah menjadi ikan cakalang asap jepit (gepe), sedangkan ikan dengan berat $<1,5 \mathrm{Kg}$ akan diolah atau diasap dalam bentuk utuh. Ikan cakalang asap jepit banyak mendapat perhatian dari para ahli untuk diteliti, untuk ikan cakalang asap utuh masih jarang diteliti padahal ikan cakalang utuh mempunyai beberapa kelebihan dibandingkan dengan ikan cakalang asap jepit (gepe). Kelebihan ikan cakalang asap utuh adalah sebagai berikut: tidak mengalami pewarnaan, waktu proses penanganan lebih singkat sehingga mutu bahan baku tidak menurun, Serta biaya produksi lebih rendah (Paputungan, et.al., 2015).

Pengasapan didefinisikan sebagai proses penetrasi senyawa volatile pada ikan yang dihasilkan dari pembakaran kayu yang dapat menghasilkan produk dengan rasa dan aroma spesifik. Umur simpan yang lama karena adanya aktivitas anti bakteri, menghambat aktivitas enzimatis pada ikan sehingga dapat mempengaruhi kualitas ikan asap. Senyawa kimia dari asap kayu umumnya berupa fenol yang berperan sebagai antioksidan, asam organik, alkohol, karbonil, hidrokarbon dan senyawa nitrogen seperti nitrooksida, aldehid, keton, ester, eter, yang menempel pada permukaan dan selanjutnya menembus ke dalam daging ikan (Isamu, et.al., 2012).

Ikan juga merupakan salah satu bahan makanan yang mudah mengalami kemunduran mutu. Kemunduran mutu ikan disebabkan oleh aksi enzimatis dan aksi bakteri. Kedua aksi ini menguraikan komponen penyusun jaringan tubuh ikan sehingga menghasilkan perubahan fisik seperti daging ikan menjadi lunak dan perubahan kimia yang menghasilkan senyawa mudah menguap dan berbau busuk (Murniyati dan Sunarman, 2000).

Salah satu penyebab terjadinya kemunduran mutu ikan asap yaitu kadar air (Agus, et.al., 2014) menyatakan bahwa kadar air merupakan parameter yang penting untuk menentukan kualitas ikan asap yang dihasilkan. Kadar air yang terkandung di dalam ikan asap dapat mempengaruhi daya simpan ikan asap. Karena kadar air merupakan media mikroba untuk berkembang biak. Menurut Buckle et.al., (1987) pengaruh kadar air sangat penting sekali dalam menentukan daya awet suatu bahan pangan karena kadar air mempengaruhi sifatsifat fisik, sifat kimia, dan kebusukan oleh mikroorganisme.

Astawan (1996) menyatakan bahwa ikan mempunyai kandungan protein tertinggi setelah air. Kandungan air pada ikan sekitar $70-80 \%$ dari berat daging. Kadar air yang tinggi akan mempermudah tumbuh dan berkembangnya mikroba pembusuk, selain itu protein pada tubuh ikan akan mudah mengalami kerusakan secara biologis serta kimiawi.

Disamping itu kondisi lingkungan sekitar berpengaruh pada jenis mikroba yang tumbuh. Hal ini disebabkan karena beberapa hal antara lain penyimpanan yang terlalu lama, suhu, $\mathrm{pH}$, kelembaban, kadar air dan kondisi lain yang spesifik.

Nilai $\mathrm{pH}$ juga merupakan salah satu indikator yang digunakan untuk menentukan tingkat kesegaran ikan. Pada proses pembusukan ikan, perubahan $\mathrm{pH}$ daging sangat besar peranannya karena berpengaruh terhadap proses autolysis dan penyerangan bakteri. Menurut Fardiaz (1992) pH yang baik untuk ikan yang diawetkan antara 2,0-5,5 sedangkan $\mathrm{pH}$ antara 6,0-8,0 merupakan media yang baik untuk pertumbuhan mikroorganisme.

Hal lain juga yang menjadi indikator penentu mutu dari ikan asap adalah kapang. Keberadaannya berpengaruh bagi mutu dan keamanan dari produk pangan karena ada jenis tertentu yang memproduksi mikotoksin (Sopandi dan Wardah, 2013). Kapang merupakan organisme eukaryotic ber sel banyak, dengan ukuran sel berkisar 20-100 mm. Organisme ini termasuk tidak bergerak, berfilamen dan bercabang. Talusnya terdiri dari sejumlah filament yang disebut hifa yang tersusun dalam sebuah kumpulan terbentuk agregat yang disebut meselium (Sopandi dan Wardah, 2013). Reproduksi hifa udara dan ekspora, konidia atau ekspora dalam kantung (Sporagium). Ukuran, bentuk dan warna spora, menjadi dasar untuk klasifikasinya (Ray, 2004).

Salah satu jenis pengolahan yang dapat digunakan untuk menghambat kegiatan zat-zat mikroorganisme adalah pengasapan ikan, selain bertujuan memberikan manfaat untuk mengawetkan ikan pengolahan ikan dengan cara pengasapan juga memberi aroma yang sedap, warna kecoklatan atau kehitaman, tekstur yang 
bagus serta cita rasa yang khas dan lezat pada daging ikan yang diolah (Wibowo, 1996).

Menurut Renate (2009), pengemasan dengan menggunakan plastik secara vakum dapat mengurangi jumlah oksigen dalam kemasan, mencegah kontaminasi mikroorganisme, dan memperpanjang umur simpan produk pangan. Selain itu kemasan vakum juga memberikan efek visual yang baik bagi makanan. Sifat-sifat permeabilitas. Kemasan plastik ini akan mempengaruhi produk yang akan disimpan secara vakum.

Penelitian ini bertujuan untuk menganalisa mutu ikan cakalang asap dari Pasar Sario dan ikan cakalang segar dari Pasar Bahu yang diolah sendiri. Manfaat penelitian ini diharapkan dapat memberikan informasi tentang mutu kimiawi dan mikrobiologi dari ikan cakalang asap dari penjual ikan di Sario dan ikan cakalang asap yang diolah sendiri dengan membandingkan penelitian yang pernah diteliti yaitu Alinti (2018) dan Angelia (2015).

\section{METODOLOGI PENELITIAN}

\section{Waktu dan Tempat Penelitian}

Penelitian ini dilaksanakan di Laboratorium Teknologi Penanganan dan Pengolahan Hasil Perikanan dan Laboratorium Pengendalian Mutu Hasil Perikanan Fakultas Perikanan dan Ilmu Kelautan Universitas Sam Ratulangi Manado. Waktu penelitian, mulai dari Desember sampai dengan April 2019.

\section{Alat dan Bahan}

Alat untuk pengujian :lemari pendingin untuk tempat penyimpanan sampel dengan kisaran suhu $4-5^{\circ} \mathrm{C}$, alumunium foil, autoclave, tabung, cawan porselen, tabung reaksi, erlenmeyer $250 \mathrm{ml}$, pipet steril $1 \mathrm{ml}$, cawan petri, inkubator, desikator, timbangan, oven, $\mathrm{pH}$ meter, tissue, bunsen, spatula, glass ukur, laminar flow, vacuum packing .wadah penyimpanan/piring, pisau.

Ikan cakalang (Katsuwonus pelamis L) asap yang dibeli di pasar Sario dan ikan cakalang segar di pasar Bahu, serabut kelapa, Plastik Kris (Size 28x40 cm).

Bahan kimia yang digunakan untuk pengujian yaitu PDA, Akuades, NaCL 0,9, larutan buffer $\mathrm{pH} 7$, silika gel.

\section{Perlakuan}

Perlakuan yang dilakukan dalam penelitian adalah sebagai berikut:
Waktu penelitian dilakukan pada hari 0 dan hari ke 7. Ulangan yang digunakan dalam penelitian adalah sebanyak 2 kali.

Perlakuan (A): jenis sampel

A1 = Diambil dari Pasar Sario

A2 = Diolah Sendiri

Perlakuan (B): penyimpanan pada suhu dingin

$\mathrm{H} 0=0$ hari penyimpanan dengan suhu $\pm 5^{\circ} \mathrm{C}$

$\mathrm{H} 7=7$ hari penyimpanan dengan suhu $\pm 5^{\circ} \mathrm{C}$

\section{Tata Laksana Penelitian}

1. Ikan cakalang asap yang dibeli di penjual ikan tradisional (Sario).

- Ikan dibungkus atau diletakkan dalam wadah plastik.

- Ikan dibersihkan dari penjepit kayu, tulang, kepala dan ekor, lalu dihaluskan dan dikemas vakum.

- Ikan disimpan pada suhu $5^{\circ} \mathrm{C}$ selama 7 hari.

2. Ikan cakalang segar dari pasar bahu yang akan diolah sendiri ,untuk perlakuan selanjutnya.

- Ikan segar di beli di Pasar tradisional (Pasar Bahu), dimasukkan ke dalam Cool Box yang berisi es Kristal dan di bawa ke laboratorium.

- Ikan dibersihkan dan disiangi, setelah itu diolah menjadi ikan asap dengan menggunakan tungku pengasapan selama 2-3 jam. Bahan bakar yang digunakan untuk proses pengasapan adalah sabut kelapa.

- Dihaluskan, dikemas vakum, ikan disimpan pada suhu $5^{\circ} \mathrm{C}$ selama 7 hari.

3. Analisa yang dilakukan meliputi pengujian kadar air, $\mathrm{pH}$ dan pengujian kapang.

4. Pengujian dilakukan secara bersamaan untuk 3 parameter uji yaitu pengujian kadar air, $\mathrm{pH}$ dan kapang dilakukan dengan 2 kali ulangan.

\section{Parameter Yang Di Uji}

Parameter yang diamati dalam penelitian ini yaitu kadar air, pH, kapang.

\section{Analisa Uji Kadar Air (AOAC, 1995)}

Analisis kadar air dengan menggunakan oven. Kadar air dihitung sebagai persen berat, artinya berapa gram berat contoh dengan yang selisih berat dari contoh yang belum diuapkan dengan contoh yang telah (dikeringkan).

Adapun prosedur analisa kadar air yang akan digunakan adalah:

1. Cawan porselen beserta tutupnya yang telah dicuci bersih, dalam keadaan kosong dimasukkan ke dalam oven yang 
temperaturnya $\quad 100-105^{\circ} \mathrm{C}$ kurang lebih selama 1 jam.

2. Cawan dipindahkan ke dalam desikator dan didinginkan selama 30 menit, kemudian ditimbang beratnya.

3. Ke dalam cawan porselen dimasukkan sampel sebanyak 2-3 gram, lalu ditimbang.

4. Cawan porselen yang telah berisi sampel dimasukkan ke dalam oven yang temperaturnya $100-105^{\circ} \mathrm{C}$ selama 3 jam.

5. Pengeringan dan penimbangan dilakukan terus sampai diperoleh berat yang konstan.

Setelah diperoleh berat yang konstan, sampel dipindahkan ke dalam desikator dan didinginkan selama 30 menit, kemudian ditimbang.

\section{Penentuan Nilai pH (AOC,1990)}

Adapun prosedur analisa $\mathrm{pH}$ yang digunakan adalah:

1. Sampel ditimbang sebanyak 5 gram kemudian ditambahkan akuades $10 \mathrm{ml}$ dan dihomogenkan selama satu menit.

2. Sampel yang sudah homogen dipindahkan ke dalam beker glass $100 \mathrm{ml}$, lalu diukur pHnya menggunakan alat $\mathrm{pH}$ meter.

3. Sebelum $\mathrm{pH}$ meter digunakan, terlebih dahulu dilakukan peneraan dengan menggunakan larutan buffer $\mathrm{pH} 4$ dan $\mathrm{pH} 7$.

4. Nilai $\mathrm{pH}$ sampel adalah nilai yang ditunjukkan oleh monitor digital pada posisi konstan.

$$
\text { Kadar air }=\frac{(B-C)}{(B-A)} \times 100 \%
$$

\section{Total Koloni Kapang (Modifikasi Fardiaz, 1993)}

1. Semua peralatan yang digunakan dalam analisa total koloni kapang disterilkan dengan menggunakan autoclave pada suhu $121^{\circ} \mathrm{C}$ dengan tekanan 15 psi selama 15 menit.

2. Disiapkan tabung reaksi yang diberi kode IIII yang berisi masing-masing $9 \mathrm{ml} \mathrm{NaCl}$ $0,9 \%$ selanjutnya disterilkan dengan menggunakan autoclave.

3. Sampel diblender hingga halus, kemudian ditimbang sebanyak 10 gram dan dimasukkan ke dalam erlenmeyer $250 \mathrm{ml}$ yang telah berisi $90 \mathrm{ml}$ larutan $\mathrm{NaCl}$ 0,9\% steril. Sampel ini merupakan pengenceran $10^{-1}$.

4. Dari larutan tersebut diambil $1 \mathrm{ml}$ dan dipindahkan ke tabung reaksi 9 ml larutan $0,9 \%$ steril dengan cara dipipet untuk mendapatkan pengenceran $10^{-2}$. Dari tabung reaksi I dipipet lagi $1 \mathrm{ml}$ dan dipindahkan ke tabung reaksi II sebagai pengenceran $10^{-3}$ demikian seterusnya sampai tabung reaksi III yang merupakan pengenceran $10^{-4}$.

5. Dari setiap pengenceran diambil masingmasing $1 \mathrm{ml}$ larutan lalu dimasukkan ke dalam dua cawan petri steril.

6. Ditimbang 13,26 gram PDA, kemudian dimasukkan dalam gelas piala yang telah berisi $340 \mathrm{ml}$ akuades, dihomogenkan dan direbus hingga mendidih, disterilkan menggunakan autoclave, lalu didinginkan.

7. Setelah PDA bersuhu $\pm 40^{\circ} \mathrm{C}$, PDA steril dimasukkan sekitar $15 \mathrm{ml}$, ke dalam cawan petri yang telah berisi $1 \mathrm{ml}$ larutan pengenceran $\left(10^{-2}, 10^{-3}, 10^{-4}\right)$, lalu dihomogenkan dengan cara digoyangkan ke kiri, kanan, depan, belakang, dan dibiarkan sampai beku. Setelah media membeku, petri disusun terbalik dalam incubator bersuhu sekitar $25-30^{\circ} \mathrm{C}$ dan diinkubasi selama 24-48 jam.

8. Pada hari ke-0 dan ke-7 dihitung jumlah koloni kapang yang bertumbuh pada media agar. Koloni yang dihitung berjumlah 30-300 koloni. Jumlah koloni kapang adalah banyaknya kapang yang dihitung dikalikan dengan satu per faktor pengenceran.

9. Total koloni kapang dapat dihitung sebagai berikut:

$$
\begin{gathered}
\text { Total Koloni Kapang }\left(\frac{\mathrm{CFU}}{\text { gram }}\right) \\
=\sum \text { Koloni } \times \frac{1}{\text { Tingkat Pengenceran }}
\end{gathered}
$$

\section{Analisa Data}

Data yang diperoleh yaitu data kuantitatif. Data kuantitatif adalah data dalam bentuk tabel-tabel, dan grafik. Data untuk uji Kadar air, pH, dan Kapang yang diperoleh, ditentukan ditabulasi dengan mencari nilai ratarata kemudian disajikan dalam bentuk tabel dan grafik. Data dari hasil pengujian laboratorium dipaparkan secara deskriptif. Selanjutnya hasil tersebut dikaji dan dibandingkan dengan persyaratan mutu ikan cakalang asap.

\section{HASIL DAN PEMBAHASAN}

\section{Kadar Air}

Berdasarkan hasil penelitian yang diperoleh nilai rata-rata kadar air ikan cakalang asap yang dari penjual ikan di Sario memiliki nilai rata-rata kadar air $62,5 \%$ dan pada produk yang diolah sendiri adalah $55 \%$ penyimpanan 0 hari. Pada penyimpanan 7 hari nilai rata-rata kadar air pada produk penjual ikan di Sario adalah $62,5 \%$ dan pada produk yang diolah sen- 
diri adalah 60\%. Berdasarkan SNI (2013) syarat kadar air ikan asap adalah maksimal $60 \%$.

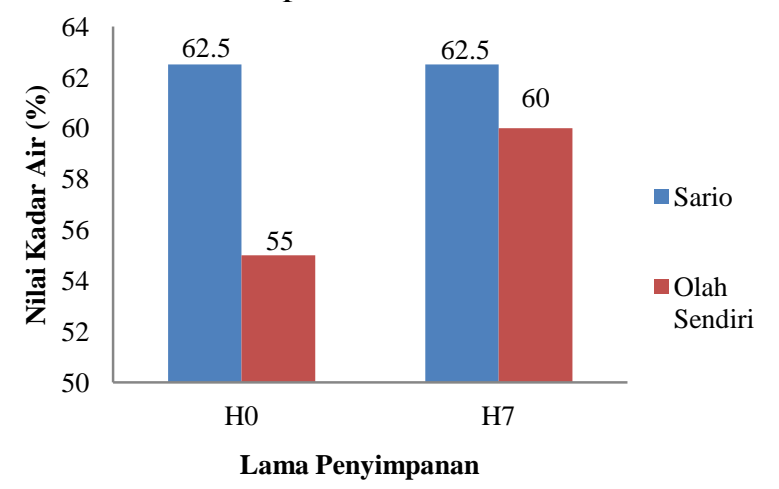

Gambar 1. Nilai kadar air ikan cakalang (Katsuwonus pelamis, L.) asap yang berasal dari penjual ikan di Sario dan ikan cakalang asap yang diolah sendiri selama penyimpanan 0 hari dan 7 hari penyimpanan pada suhu $\pm 5^{\circ} \mathrm{C}$.

Berdasarkan data yang diperoleh menunjukkan bahwa nilai kadar air sampel ikan cakalang asap yang diolah sendiri mengalami kenaikan di hari ke 7 sedangkan nilai kadar air sampel ikan cakalang dari penjual ikan di Sario tidak mengalami perubahan di hari ke7 (stabil). Winarno (1980) menyatakan bahwa kadar air suatu produk dipengaruhi oleh kelembaban nisbi yaitu perbandingan antara aktual dengan kapasitas udara untuk menampung uap air.

Peningkatan kadar air tersebut kemungkinan juga disebabkan oleh terserapnya uap air yang ada di lingkungan sekitar atau dalam kulkas meskipun telah dikemas plastik vakum, karena plastik memiliki sifat permeabilitas terhadap gas dan uap air, bentuk dan permukaannya, maka akan memudahkan uap air dapat terserap ke dalam ikan. Hal ini karena adanya perbedaan tekanan di dalam dan di luar kemasan akan mengakibatkan masuknya uap air ke dalam kemasan dan uap air tersebut diserap oleh produk sehingga menaikkan kadar air produk selama penyimpanan (Ishak dan Amrullah, 1984). Tingginya kadar air pada produk yang dikemas sehingga menyebabkan tingginya kelembaban dalam plastik sebagai pengemas dan menyebabkan mikroba dapat tumbuh dengan cepat.

Kadar air merupakan parameter yang penting untuk menentukan kualitas ikan asap yang dihasilkan. Kadar air yang terkandung di dalam ikan asap dapat mempengaruhi daya simpan ikan asap. Karena kadar air merupakan media mikroba untuk berkembang biak (Agus, et.al., 2014).
Nilai Standar kadar air ikan asap berdasarkan SNI (2013) adalah maksimal 60\%. Hasil penelitian menunjukkan produk ikan asap yang dibeli dari penjual ikan di Sario pada penyimpanan dingin mulai dari hari ke-0 hingga hari ke-7 tidak memenuhi standar yang telah ditentukan oleh SNI (2013), sedangkan produk yang diolah sendiri pada penyimpanan 0 hari sampai 7 hari mengalami kenaikan kadar air namun masih memenuhi syarat yang telah ditentukan oleh SNI (2013). Dari penelitian ini dapat dihubungkan atau dibandingkan dengan penelitian yang ada oleh Alinti (2017) dan Gabriella (2015) yaitu ikan cakalang asap cair dan ikan cakalang asap konvensional memiliki nilai kadar air yang masih memenuhi SNI (2013) yaitu di bawah $60 \%$.

\section{Penentuan Derajat Keasaman}

Nilai rata-rata $\mathrm{pH}$ ikan cakalang dari penjual ikan di Sario penyimpanan 0 hari adalah 5,78 sedangkan pada produk olahan sendiri adalah 5,64. Pada penyimpanan 7 hari nilai rata-rata $\mathrm{pH}$ pada produk ikan cakalang penjual di Sario 6,25 dan produk olahan sendiri adalah 5,92. Dari data ini dapat dibuat suatu hubungan antara lama penyimpanan terhadap nilai $\mathrm{pH}$ ikan cakalang asap dari Pasar Sario dan olah sendiri yang dikemas vakum.

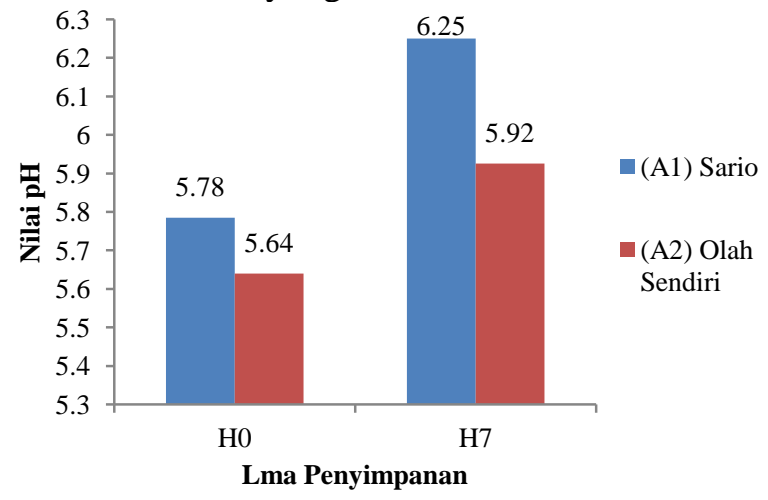

Gambar 2. Nilai pH ikan cakalang (Katsuwonus pelamis, L.) asap selama penyimpanan 0 hari dan 7 hari penyimpanan pada suhu $\pm 5^{\circ} \mathrm{C}$.

Gambar 2 menunjukkan bahwa nilai $\mathrm{pH}$ H0-H7 penjual ikan di Sario dan yang diolah sendiri mengalami kenaikan, sampel penjual ikan di Sario pada penyimpanan $\mathrm{H} 7$ yaitu 6,25 merupakan media yang baik untuk pertumbuhan mikroorganisme. Hal ini menunjukkan semakin rendah suhu yang digunakan maka aktivitas enzim semakin terhambat selama penyimpanan dapat dilihat bahwa sampel yang berasal dari Sario dan yang diolah sendiri mengalami 
kenaikan $\mathrm{pH}$ disebabkan karena menurut Hadiwiyato (1993) daging ikan yang mempunyai $\mathrm{pH}$ tinggi disebabkan karena timbulnya senyawa-senyawa yang bersifat basa seperti amoniak, trimetilamin, dan senyawasenyawa volatile lainnya. Proses glikolisis, enzim sangat berperan sampai terbentuknya asam laktat. Hal ini menyebabkan akumulasi asam laktat berjalan lebih lambat sehingga penurunan $\mathrm{pH}$ ikan juga berlangsung lebih lambat (Munandar dan Aris, 2009).

Chamidah (2000) menyatakan bahwa selama penyimpanan terjadi penguraian protein menjadi senyawa basa antara lain amoniak. Nilai pH bahan pangan selama penyimpanan dapat berubah karena adanya protein yang terurai oleh enzim proteolitik dan bantuan bakteri menjadi asam karboksilat, asam sulfida, amoniak dan jenis asam lainnya. Oleh karena itu nilai $\mathrm{pH}$ ikan cakalang asap yang dihasilkan walaupun meningkat tetapi masih pada kondisi asam. Nilai $\mathrm{pH}$ merupakan salah satu indikator yang digunakan untuk menentukan tingkat kesegaran ikan. Pada proses pembusukan ikan, perubahan $\mathrm{pH}$ daging sangat besar peranannya karena berpengaruh terhadap proses autolysis dan penyerangan bakteri.

Menurut Fardiaz (1992) pH yang baik untuk ikan yang diawetkan antara 2,0-5,5 sedangkan $\mathrm{pH}$ antara 6,0-8,0 merupakan media yang baik untuk pertumbuhan mikroorganisme. Nilai $\mathrm{pH}$ yang didapat pada penelitian ini pada produk ikan cakalang asap yang berasal dari Pasar Sario pada penyimpanan 0-7 hari sudah tidak memenuhi kriteria mutu yang baik sedangkan pada produk olahan sendiri penyimpanan 0-7 hari masih memenuhi syarat mutu yang meskipun mengalami kenaikan yang cepat dibandingkan dengan penelitian oleh Alinti (2017) dan Gabriella (2015) memiliki nilai $\mathrm{pH}$ yang stabil pada pengemasan vakum dan penyimpanan suhu dingin 0 sampai 7 hari dengan nilai yang stabil di bawah 6,0 .

\section{Total Koloni Kapang}

Kapang termasuk salah satu jenis mikroba yang sering ditemui pada hasil perikanan dan produk olahannya, oleh sebab itu kapang menjadi salah satu parameter untuk menentukan mutu dari produk olahan perikanan. Berdasarkan hasil penelitian total koloni kapang pada ikan cakalang asap selama penyimpanan pada produk yang dikemas vakum juga pada ikan cakalang asap konvensional dapat dilihat pada Tabel 1.

Tabel 1. Hasil total koloni kapang.

\begin{tabular}{lcr}
\multicolumn{1}{c}{ Sampel } & $\begin{array}{c}\text { Lama } \\
\text { penyimpanan }\end{array}$ & $\begin{array}{c}\text { Total koloni } \\
\text { Kapang (Log CFU/gr) }\end{array}$ \\
\hline Ikan Cakalang Asap Dari & $\mathrm{H} 0$ & $1,3 \times 10^{3}$ \\
penjual ikan di Sario & $\mathrm{H} 7$ & $8,9 \times 10^{3}$ \\
Ikan Cakalang Olahan & $\mathrm{H} 0$ & $2,1 \times 10^{3}$ \\
Sendiri & $\mathrm{H} 7$ & $6,8 \times 10^{3}$ \\
\hline
\end{tabular}

Dari hasil yang ditunjukkan pada tabel di atas bahwa total koloni kapang ikan cakalang asap yang berasal dari penjual ikan di Sario pada penyimpanan 0 hari adalah $1,3 \times 10^{3}$ CFU/gr, pada penyimpanan hari ke 7 memiliki

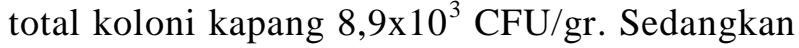
total koloni kapang pada ikan cakalang olahan Sendiri pada penyimpanan 0 hari adalah $2,1 \times 10^{3} \mathrm{CFU} / g r$ dan pada penyimpanan hari ke7 adalah $6,8 \times 10^{3} \mathrm{CFU} / \mathrm{gr}$.

Pada hasil penelitian menyatakan bahwa ikan cakalang asap yang berasal dari penjual ikan di Sario dan olahan sudah tidak memiliki mutu yang baik sampai penyimpanan hari ke 7 , karena total kapang yang memenuhi syarat Standar Nasional Indonesia ( $<100 \mathrm{CFU} / \mathrm{gr})$.

Dari hasil penelitian ini dapat dibandingkan dengan penelitian Alinti (2013) yang menyatakan bahwa ikan cakalang asap cair yang dikemas vakum masih memiliki mutu yang baik sampai penyimpanan ke 21 hari, karena total kapang memenuhi SNI $(<100$ CFU/gr). Sedangkan cakalang asap cair non vakum dan konvensional hanya memiliki mutu yang baik sampai penyimpanan 7 hari.

Hal ini dikarenakan pada pengemasan vakum bakteri pembusuk aerob yang ada akan dihambat oleh kondisi lingkungan anaerob pengemasan vakum. Dengan ketiadaan udara dalam kemasan, maka kerusakan akibat oksidasi dapat dihilangkan sehingga kesegaran produk yang dikemas akan lebih bertahan 3-5 kali lebih lama daripada produk yang dikemas dengan pengemasan non-vakum (Jay, 1996 dalam Gabriella et.al.., 2015).

Menurut Anonimous (1995) dalam Malikul (2003) menyatakan, tingginya total koloni kapang kemungkinan disebabkan sampel telah terkontaminasi pada saat penyimpanan dan penjualan. Disamping itu kemungkinan karena produk ikan cakalang asap dijual hanya diletakkan di tempat terbuka tanpa wadah atau bahan pengemas, keadaan sekitar pasar tersebut yang dekat dengan jalan raya dan kondisi lingkungan yang kotor menjadi sumber 
kontaminasi kapang, dan penyimpanan stok yang menumpuk dan terlalu lama disimpan.

Menurut Fardiaz (1992), beberapa kapang mengeluarkan komponen yang dapat menghambat pertumbuhan organisme lainnya. Komponen ini disebut antibiotik, misalnya penisilin yang diproduksi oleh Penicillium chrysogenum, dan clavasin yang diproduksi oleh Aspergillus clavatus. Sebaliknya, beberapa komponen lain bersifat mikostatik atau fungistatik, yaitu menghambat pertumbuhan kapang, misalnya asam sorbat, propionat dan asetat, atau bersifat fungisidal yaitu membunuh kapang.

\section{KESIMPULAN DAN SARAN}

\section{Kesimpulan}

Berdasarkan hasil penelitian yang dilakukan, maka dapat ditarik kesimpulan sebagai berikut:

1. Berdasarkan hasil uji nilai rata-rata kadar air ikan cakalang (Katsuwonus pelamis, L.) dari penjual ikan di Sario penyimpanan $\mathrm{H} 0-\mathrm{H} 7$ tidak memenuhi kriteria mutu yang baik, sedangkan pada produk olahan sendiri penyimpanan H0-H7 masih memenuhi kriteria mutu yang baik menurut SNI (2013).

2. Berdasarkan hasil uji nilai $\mathrm{pH}$ ikan cakalang yang diolah sendiri pada penyimpanan $\mathrm{HO}$ $\mathrm{H} 7$ tidak memenuhi dalam kriteria mutu yang baik menurut SNI (Standar Nasional Indonesia) sedangkan dari Pasar Sario mengalami kenaikan pada hari ke 7 dan merupakan media yang baik untuk pertumbuhan mikroorganisme.

3. Berdasarkan hasil uji kapang ikan cakalang dari penjual ikan di Sario dengan yang diolah sendiri tidak memenuhi kriteria mutu yang baik menurut SNI (2013) yaitu $1,0 \times 10^{2}$.

\section{Saran}

Perlu penelitian lanjutan tentang aplikasi jenis atau menggunakan jenis plastik lain, ketebalan plastik ,identifikasi jenis kapang terhadap mutu ikan cakalang (Katsuwonus pelamis L) asap kemasan vakum yang disimpan dingin.

\section{DAFTAR PUSTAKA}

Adwyah, R. 2008. Pengolahan dan Pengawetan Ikan. Penerbit. Bumi Aksara. Jakarta

Agus. T.S.W., F. Swastawati, da A.P. Anggo. 2014. Kualitas Ikan Pari (Dasyatis sp) Asap Yang Diolah Dengan Ketinggian Tungku Dan Suhu Yang Berbeda.
Jurnal Pengolahan dan Bioteknologi Hasil Perikanan, vol 3. No.1 hal 147-156

Ali, A., 2005. Mikrobiologi Dasar Jilid I. State University of Makassar Press. Makassar.

Alinti, Zulviki., Timbowo, S.M., Mentang, F. 2017. Studi Kadar Air, pH dan Kapang Ikan Cakalang (Katsuwonus pelamis, L.) Asap Cair yang Dikemas Vakum dan Non Vakum Pada Penyimpanan Dingin. Jurnal Media Teknologi Hasil Perikanan, Vol. 6, No. 1, Januari 2018.

(AOAC) Assocation of Official Analytical and Chemistry. 1995. Official Methods of Analysis. Penentuan Kadar Air Bahan Pangan.

(AOAC). 1990. Official Methods of Analysis. Penentuan kadar derajat keasamaan $(\mathrm{pH})$.

Angela, G.C., Mentang, Feny., Sanger, G. 2015. Kajian Ikan Cakalang (Katsuwonus pelamis, L.) Asap Dari Tempat Pengasapan Desa Girian Atas Yang Dikemas Vakum Dan Non Vakum Selama Penyimpanan Dingin. Jurnal Media Teknologi Hasil Perikanan, Vol. 3, No. 2.

Anonimous, 1993."Jurnal Penelitian Laut". Balai Penelitian dan Pengembangan Pertanian. Jakarta.

Astawan. M. 1996. Pengetahuan Bahan Hasil Perikanan \& Faktor Penyebab Kerusakan. Jurusan Teknologi Pangan \& Gizi Fakultas Teknologi Pertanian IPB. Bogor.

Bawinto, A., Mongi, E., Kaseger, B.E. 2015. Analisa Kadar Air, pH, Organoleptik Dan Kapang Pada Produk Ikan Tuna (Thunnus sp) Asap, Di Kelurahan Girian Bawah. Kota Bitung. Sulawesi Utara. Jurnal Media Teknologi Hasil Perikanan, Vol. 3, No. 2.

Buckle, K.A., R.A. Edwards., G.A. Fleet., dan M. Wooton. (1987). Food science. (Penerjemah: Hari Purnomo dan Adiono, Judul: Ilmu Pangan). Universitas Indonesia.

Chamidah, A., Tjahyono, A., dan Rosidi, D. (2000). Penggunaan metode pengasapan cair dalam pengembangan ikan bandeng asap tradisional. Jurnal Ilmu-ilmu Teknik. Volume 12. No.1.

Desrosier. N. W., 1988. Teknologi Pengawetan Pangan. Terjemahan. Mulitjoharto UI-Press. Jakarta.

Dwidjoseputro, 1981. Dasar-Dasar Mikrobiologi. Penerbit Djambatan. Jakarta.

Fardiaz. S., 1982. "Mikrobiologi Pangan". Jilid 1. Jurusan Ilmu dan Teknologi Perikanan. Jakarta.

Fardiaz. S., 1992. Mikrobiologi Pangan I. Penerbit Gramedia Pustaka Utama. Jakarta.

Fardiaz. S., 1993. Analisis Mikrobiologi Pangan. PT. Raja Grasida Persada Utama. Jakarta.

Harikedua, J. W. 1994.Pengantar Teknologi Pengolahan Hasil Perikanan. Materi Kuliah. Fak. Perikanan. Manado.

Hadiwiyoto, S. 1993. Teknologi Pengolahan Hasil Perikanan. Jilid I. Penerbit Liberty. Yogyakarta.

Hadiwiyoto S, Darmadji P, Purwasari SR. 2000. Pendinginan Pengasapaan Panas Dan Penggunaan Asap Cair Pada Pengolahan Ikan; Tinjauan Kandungan Benzopiren, Fenol, dan Sifat Organoleptik Ikan Asap. Agritech 20:14-19. 
Ilyas, S.1993.Teknologi Refrigerasi Hasil Perikanan Jilid II. Penerbit CV. Paripurna, Jakarta.

Ilyas, S, 1983. "Teknologi Refrigrasi Hasil Perikanan". Jilid 1. Teknik Pendinginan Ikan. C. V. Paripurna, Jakarta.

Irawan, A. 1995. Pengolahan Hasil Perikanan Home Industri, Usaha Perikanan dan Mengkomersikan Hasil Sampingan, CV. Aneka. Solo.

Isamu Kobajashi T., Hari Purnomo Dan Sudarminto S. Yuwono. 2012. Karakteristik Fisik, Kimia dan Organoleptik Ikan Cakalang (Katsuwonus Pelamis) Asap Di Kendari. Jurnal Teknologi Pertanian Vol. 13 No. 2 105-110.

Ishak, Elly dan Sarinah Amrullah. 1985. Ilmu dan Teknologi Pangan. Badan Kerjasama Perguruan Tinggi Negeri Bagian Timur. Ujung Pandang.

Jay. 1996. Modern Food Microbiology 4th edition. New York : D Von Nostrand Company.

Juniarto. 2003. Teknik Penanganan Ikan. Penebar Swadaya. Jakarta.

Kose, S. 2003. An Investigation of Quality In Anchovy (Engraulis ancarasicolus). Stored at Different Temperaturs. Turk J Vet Anim Sci 28 ; 575-582.

Liston. J., 1980 Microbiologic in Fisheries Science Dalam Advance Publishing. Inc New York.

Malikul, Asmi. 2003. Kapang Pada Ikan Roa (Hemirhampus sp) Asap Dari Pasar Ikan Tua Manado. Skripsi. Manado. Fakultas Perikanan Dan Ilmu Kelautan. Universitas Sam Ratulangi Manado.

Moeljanto. 1992. Pengawetan dan Pengolahan Hasil Perikanan. Penebar Swadaya. Jakarta.

Murniyati Murniyati, A. S. dan Sunarman. 2000. Pendinginan, Pembekuan, dan Pengawetan Ikan. Yogyakarta: Kanisius.

Paputungan, Tri Sutrisno., Wonggo, D., Damongilala., L. J. 2015. Kajian Mutu Ikan Cakalang (Katsuwonus Pelamis L.) Asap Utuh Yang Dikemas Vakum Dan Non Vakum Selama Proses Penyimpanan Pada Suhu Ruang. Jurnal Media Teknologi Hasil Perikanan, Vol.3, No. 2.

Ray, 2004. Fundamental Food Microbiology. CRC. Press: Boca Raton. $493 \mathrm{~h}$.

Rahayu K., Kuswanto., S. dan Suklarmadji. S., 1988. Proses-Proses Mikrobiologi Pangan. Pusat antar Universitas Pangan dan Gizi. Proyek Peningkatan/ Pengembangan Perguruan Tinggi. Universitas Gadjah Mada. Yogjakarta.
Renate, Dharia. 2009. Pengemasan Puree Cabe Merah dengan Berbagai Jenis Plastik Yang Dikemas Vakum (Packaging of Red Chilli Puree with Various Types of Plastic vacum Packaged). Jurnal Teknologi Industri dan Hasil Pertanian. Vol.14, No. 1.

Saanin, 1968. Taksonomi dan Kunci Indentifikasi Ikan II. Pt. bina Cipta. Bogor. Jawa Barat

Sanger, Grace. 2010. Oksidasi Lemak Ikan Tongkol (Auxfs thazardl) Asap Yang Direndam Dalam Larutan Ekstrak Daun Sirih.Pacific Journal Juli 2010 Vol 2 (5) : 870 -873.

Serly, K . 1998 . Pengaruh Cara Pengemasan dan Lama Penyimpanan Pada Suhu Dingin Terhadap Mutu Dendeng Ikan CUCUT (Carcharhinus limbatus). [Skripsi]. Manado. Fakultas Perikanan Dan Ilmu Kelautan Unsrat.

(SNI) Standard Nasional Indonesia. 2013. Ikan Asap Bagian 1. Spesifikasi. SNI 27 25.1:2013. Badan Standardisasi Nasional. Jakarta.

Soepandi. T. Dan Wardah. 2013. Microbiologi Pangan. Teori dan Praktek. Andy Yogyakarta. $493 \mathrm{~h}$.

Suwetja, I.K. 2011. Biokimia Hasil Perikanan, buku. Diterbitkan Oleh Media Prima Aksara. Jakarta. 204h.

Sunarsih, S., Y. Pratiwi., dan Y. Sunarto. 2012. Pengaruh Suhu, Waktu Dan Kadar Air Pada Pembuatan Asap Cair Dari Limbah Padat Pati Aren. Prosiding Seminar Nasional Aplikasi Sains dan Teknologi (SNAST) Periode III. Yogyakarta 3 November 2012. ISSN: 1979-911X.

Swastawati, Fronthea. 2011. Studi Kelayakan Dan Efisiensi Usaha Pengasapan Ikan Dengan Asap Cair Limbah Pertanian. Fakultas Perikanan Dan Ilmu Kelautan Universitas Diponegoro. Semarang

Tampubolon, S.M., 1983. Tuna dan Perdagangannya. Fakultas Perikanan IPB. Bogor.

Tranggono dan Sutardi. 1990. Biokimia dan Teknologi Pasca Panen. Universitas gadjah mada:Yogyakarta

Utomo, B.S.B., S. Wibowo., dan T.N. Widianto. 2012. Asap Cair. Cara Membuat dan Aplikasinya pada Pengolahan Ikan. Penerbit. Bumi Aksara.

Waluyo, L., 2004. Mikrobiologi Umum. UMM Press. Malang.

Wibowo, S. 1996. Industri Pengasapan Ikan. Penebar Swadaya. Jakarta

Winarno, 1993. "Pangan dan Gizi". Teknologi dan Konsumen". PT. Gramedia Pustaka Utama. Jakarta.

Winarno, F.G. 1997. Kimia Pangan dan Gizi. Gramedia; Jakarta. 